\title{
Growth Opportunities Utilization Inter-Industry
}

\author{
S.Martono ${ }^{1, *}$, Arief Yulianto ${ }^{2}$ and Angga Pandu Wijaya ${ }^{3}$ \\ 1 Department of Management, Universitas Negeri Semarang; martono@mail.unnes.ac.id (S.M) \\ 2 Department of Management, Universitas Negeri Semarang; ariefyulianto@mail.unnes.ac.id (A.Y) \\ 3 Department of Management, Universitas Negeri Semarang; apwijaya@mail.unnes.ac.id (A.P.W) \\ * Correspondence: martono@mail.unnes.ac.id; (S.M)
}

\begin{abstract}
Inter-industry has various capital structures to take advantage of growth opportunities due to agency differences and information asymmetric problems. This research aims to analyze: (1) the differences in leverage between industries; (2) the impact of shareholders-debtholders conflict and information asymmetric on growth opportunities. The findings show that there are differences in leverage between industries. However, they are relatively stable and not excessive for assets to prevent conflicts between managers and shareholders and debtholders. Equity is also not used to utilize growth because it is used to reduce the discretionary power (dilution) of shareholders. As a result, the use of opportunities and growth is limited.
\end{abstract}

Keywords: Growth Opportunities, Inter-Industry, Leverage

\section{How to Use This Template}

The template details the sections that can be used in a manuscript. Note that each section has a corresponding style, which can be found in the "Styles" menu of Word. Sections that are not mandatory are listed as such. The section titles given are for articles. Review papers and other article types have a more flexible structure.

Remove this paragraph and start section numbering with 1 . For any questions, please contact the editorial office of the journal or support@mdpi.com.

\section{Introduction}

Previous literature has discussed the relationship between modern companies' roles and functions, assuming widely dispersed ownership. However, different results are found in large companies outside the US, which tend to be owned by controlling shareholders through excess of their cash flow rights (La Porta et al., 1999). In Indonesia, Japan, and Singapore, more than two-thirds of companies are owned by single shareholders (Claessens et al., 2000). Separation of ownership and control functions is rarely carried out, and around $60 \%$ of top management are family members who also act as shareholders.

This study elaborates and develops on the research conducted by Claessens et al., (2000) on findings in Indonesia through two perspectives: agency theory and asymmetric information theory. The agency theory refers to when managers act independently from the company shareholders' interests. For example, they might reject a potential net Present Value (NPV) project as long as they benefit debtholders (Myers, 1977). As an implication, the company could lose growth opportunities (La Rocca et al., 2007). The second theory asymmetric information - results in debtholders preventing opportunistic behavior by limiting debt and increasing interest rates (Cariola et al., 2011).

This study finds extensive research related to underinvestment problems resulting in lost growth opportunities (Claessens et al., 2000). Between 2009 - 2019, debt use tended to be stable, indicating that companies have prevented debt from an overhang. As a result, it does not exploit growth opportunities. Senior shareholders will avoid issuing shares that result in dilution or loss of discretionary power for Indonesian companies 
characterized by a controlling shareholder's existence. Older companies have a lower level of asymmetric information and vice versa. This situation causes companies' conditions to be independent of debt because it could take advantage of equity, thereby taking advantage of growth opportunities.

The evidence also suggests that there is a slight difference in leverage, age, and size of the firm due to the type of industry, namely $16.9 \%, 2.3 \%, 3.9 \%$, respectively. Even though growth opportunities are inter-industrial, companies still prefer to limit debt. Only older companies with low information asymmetry will reduce the utilization of growth opportunities. Interestingly, previous research found that to avoid the opportunity to lower growth opportunity, shareholders would limit conflict with debtholders while simultaneously avoiding investing in new shares that could cause dilution. Warjiyo (2015) explained that Indonesia has a strong bank-based system compared to the capital market, causing banks to offer many debts to the companies. This bank-based system's presence causes weak good governance, which in 1998 caused an economic crisis (Sadia et al., 2013). The existence of excessive debt and concentrated majority ownership on shareholders causes many multiplier effects on bankruptcies and lost opportunities to take advantage of growth across industries. This situation encourages companies to auction off assets to fulfill their obligations to debtholders without providing shareholders benefits. Therefore, this research aims to analyze and test the difference in inter-industry debt ratios after 20 years of crisis. Furthermore, this study identifies agency problems and asymmetric information that determines independent companies' decisions in exploiting growth opportunities.

\section{Literature Review}

\section{Agency Problem and Asymmetric Information}

The conflict between managers, shareholders, and debtholders is caused by differences in the interests of in-place financing assets to take advantage of growth opportunities based on the ability to generate profitable investments. With information asymmetry and incomplete nexus-contracts, this conflict could lead managers to act based on two interests: their interest as a debtholder or as a shareholder (Cariola et al., 2011; La Rocca et al., 2007). Suppose they act base on their interests as a debtholder. In that case, the investment decision could be detrimental to shareholders' interests because debtholders are prone to making riskless investments despite low returns. On the other hand, investments made in shareholders' interests through suboptimal investments, oriented to maximizing equity value and not corporate value, could also be detrimental to debtholders. In turn, this could elicit conflict between senior-new shareholders.

The underinvestment problem is related to debt overhang (Myers, 1977). Companies with high leverage and managers who act in the interests of shareholders will reject positive NPV projects. For debtors, debt becomes riskier (risky debt) because of the increased risk of financial difficulties and company bankruptcy. Ultimately the debt does not pay off. On the other hand, the manager will not choose the project because it only benefits debtholders without shareholders' additional benefits. This situation resulted in a conflict of interest for shareholders and debtholders due to a debt overhang. Debt is a "tax" because the company must firstly pay principal and loan interest to debtholders while shareholders only receive its' residual (Stein, 2001). Even though the project has a positive NPV, as long as it does not provide significant benefits to shareholders, the manager would refuse (underinvestment), thus becoming a risky debt for debtholders. When the company is independent and has an overhang, the impact on reducing investment incentives is that opportunities to exploit growth are limited (Mondosha \& Majoni, 2018). When assets in place are financed by debt, it influences the decision to take advantage of and create growth opportunities. Because in this way, it puts pressure on the quality of investment decision, which is based not only on cash flow but also on the project's ability to provide more residuals to shareholders (Cariola et al., 2011). This situation resulted in the indebted 
company losing the opportunity to grow because it refuses all projects that only benefit debtholders.

Specifically, investment choices are related to growth opportunities and financial conditions (Brito \& John, 2002; Cariola et al., 2011),. First, when growth opportunities are high and financial conditions are good, the optimal investment will occur. Second, when growth opportunities are low and financial conditions are poor (high leverage), debt overhang or underinvestment occurs (Myers, 1977). Third, when growth opportunities are high and financial conditions are bad (Leverage is high), risk-avoidance occurs (Brito \& John, 2002). Conversely, when growth opportunities are low and financial conditions are poor (high leverage), risk-shifting occurs (Jensen \& Meckling, 1976). So this high leverage situation generates various possibilities for the discretion of managers who side with the interests of shareholders, who explores the use of growth opportunities.

Apart from agency problems caused by manager discretion in allocating investment resources, it can also be caused by asymmetric information (Degryse \& Jong, 2001). The presence of untapped growth opportunities creates agency costs of risky debt, such as risk avoidance, risk shifting, underinvestment. This agency problem produces information asymmetry between shareholders (managers) and debtholders. When debtholders cannot determine the quality of information regarding shareholders' investment decisions (asymmetric information), it will increase the agency cost of debt. It will limit lending and increase interest rates. The presence of new shares results in a dilution, reducing the power of the past stakeholders. As an implication, conflicts between new and old shareholders arose (Cariola et al., 2011).

The information asymmetry problem is generated because debtholders prevent managers' opportunistic behavior from acting on shareholders' interests. Such cases are found in specific firm forms, such as their age and size (Degryse \& Jong, 2001). Information from older companies is more exposed than younger firms (Tayem, 2018), lowering the level of asymmetric information. In addition to firm age, asymmetric information is generated from firm size. Large companies tend to have fewer information asymmetry problems, whereas small companies with high growth have a higher level of information asymmetry (Frank \& Goyal, 2003; Tayem, 2018). Having better good governance and financial analysts and becoming public attention - causes larger companies to have lower information asymmetry levels (Hwang et al., 2019). In other words, older and larger companies have less asymmetric information, allowing them to obtain equity funding when a debt overhang occurs. At the same time, companies can continue to take advantage of growth opportunities other than debt.

The second part of this paper explains the literature review about the differences between inter-industry leverages and the relationship between leverage and growth with specific inter-industry firms. Section 3 describes the data, and section 4 describes finding and results. Finally, section 5 was done with a conclusion.

\section{Leverage Inter-Industry}

This paper divides the explanation of industries' leverage variation based on two causes: agency problems and asymmetric information. First, the global crisis of 1997-1998 and the bailout in Europe in 2008 significantly impacted Indonesia. They provided lessons for private sectors about the need to reduce the debt ratio in anticipation of increased risk (Nursechafia \& Muthohharoh, 2014). The crisis was caused by the weak implementation of corporate governance with family control, business group affiliation, cash flow control, and political connections (Harijono \& Tanewski, 2012). All companies across industries have excessive debt ratios, so the impact of the crisis is across industries. As a result, shareholders do not receive any residual because the bankruptcy effect leaves debtors to fulfill obligations that must be fulfilled.

In this research, the influence of the 1998 crisis is not taken into consideration because it is no longer relevant to the present situation. The current situation is more accurately described as a pre-crisis form. The differences in risk cause differences in the inter-industry leverage. However, the intra-industry leverage level is relatively similar due to its' 
business and risk homogeneity that tends to be stable over time (Das \& Roy, 2007). They explained that leverage between industries tends to vary, depending on industry characteristics. In industries with low growth and high leverage, managers' decisions limit investment. Companies in the same industry have relatively no different capital structures (e.g., computer software, oilfield services, pharmaceutical). However, in other industries, the capital structure is entirely different (e.g., aluminum, food wholesale, drugstores) (Almazan \& Molina, 2005). More specifically, companies with more leverage than the target will reduce investment capital expenditures, which does not happen to under-leveraged companies. Thus, inter-industry leverage varies, depending on the agency problem that results from inherent leverage.

Second, the difference in leverage between industries is due to the asymmetric information produced by variations in the inter-industry companies' size and age. Some literature finds that firm size is inversely related to information asymmetry (Degryse \& Jong, 2001). They specifically explained that greater information asymmetry is found in smaller firms because of the high cost of obtaining information. Additionally, fixed assets are easier to value than non-fixed assets. Hence, companies with more considerable fixed assets can use them as collateral to limit financial constraints. The three company track records are visible from age. Older companies have lower information asymmetry by providing information that is easily accessible to the public. Also, inter-industry has different characteristics from the debtors' perspective, such as the need for assets and the business cycle (Leclerc, 2016).

Furthermore, large-sized companies have more funding options compared to smallsized companies. Age, measured since going public, impacts funding sources' heterogeneity (Almazan \& Molina, 2005). Large companies have better governance and better disclosure, so that information asymmetry is lower-this difference in information asymmetry results in the differences in independent companies' opportunity to grow.

This study employs industry measurements - variations in mean leverage between industries (Graham \& Leary, 2011). This choice is made because of the assumption that the mean leverage between industries is not different (Das \& Roy, 2007). Also, time-series data is used to determine variations in leverage as a proxy agency problem and information asymmetry. The increase in leverage time series shows the potential for a debt overhang to occur, which could produce conflict between shareholders and debtholders. Additionally, ex-ante information asymmetry results in a decrease in leverage.

Effect of Leverage, Firm Age, and Firm Size on Growth

Manager's discretion in increasing firm value depends on the ability to choose a profitable investment based on future growth opportunities (Myers, 1977). With discretionary power, they can make decisions based on shareholders' interests, potentially causing conflicts with debtholders, such as underinvestment (Cariola et al., 2011; Jensen \& Meckling, 1976).

When managers make decisions to increase firm value, they select all projects with a positive NPV, but high debt prompts them to act entirely differently. The presence of high debt as risky debt results in their decision to reject a project with a positive NPV because, if the investment is successful, it will only benefit the debtholder, namely debt market value exceeds the nominal value without generating benefits for shareholders (Cariola et al., 2011; Myers, 1977). If the investment fails, they must still pay debts and principal loans to debtholders, such as the tax on profit from the investment made (Stein, 2001).

Underinvestment due to agency problems and ex-ante information asymmetry causes debtholders to make adverse choices - preventing managers and shareholders' opportunistic behavior by limiting credit or increasing loan interest rates. The uncertainty regarding the quality of investment information has resulted in risky debt and increased debt costs for debtholders. This condition encourages various actions from the managers. First, a risky debt would drive managers to reject projects with positive NPV, which could cause them to lose growth opportunities. Thus, higher leverage increases the chance for 
projects with positive NPV to be rejected. The underinvestment hypothesis explains that risky debt decreases debt from the total resources meant for new investments.

Hypothesis 1: the number of resources for new investments is lower than planned, limiting companies from taking growth opportunities and creating economic value.

The second hypothesis related to risk is risk-shifting; Leverage positively affects growth opportunities (Jensen \& Meckling, 1976). They explained that shareholders would invest when the level of risk is above average. The fact is that companies do risk-shifting when there is an increase in leverage, so there is an increase in the risk of bankruptcy and financial difficulties. Contrary, risk avoidance, namely the increase in leverage, does not significantly impact investment in growth opportunities (Brito \& John, 2002). Managers tend to make investment decisions that do not exceed the average risk for peers, to protect their control over the company. This situation can ultimately lower future growth opportunities.

The demand for the premium cost of debt can be reduced by the presence of a debt covenant, which can control the conflict between shareholders and debtors over the implementation of growth options so that high-growth companies use low debt (Billett et al., 2007). Apart from the Anglo and American models, debt covenants are different in large developing economies such as China, India, Brazil, and second-tier developing economies such as Indonesia and South Africa, and new market economies as Russia (Taylor, 2013). In Indonesia, debt covenants' implementation has not reduced debtholders and share methods' conflicts, so there is still high interest for indebted companies (Rossieta, 2009). So in the absence of a debt covenant, information asymmetry results in debtholder precautions against managers and shareholders through an increase in the interest rate.

Consequently, companies choose to invest in lower debt options, even though it offers high growth opportunities (Ari, 2017; Billett et al., 2007). Growth opportunities are not utilized in debt overhang companies with a high level of asymmetry.

Hypothesis 2: Large and older companies have a lower level of asymmetry, which allows them to have equity funding when a debt overhang occurs

\section{Research Method}

Industry classification is based on the Indonesia Stock Exchange and the financial industry division, such as banking, financing institutions, insurance, because we have different capital structures. The 1st and 100th percentiles of the sample data (i.e., leverage, growth, firm size, and age) have been removed to obtain balanced data because it contains extreme values and the population distribution is unknown (Müller, 2011). All results reported in this paper relate to trimmed data.

The firm-level data used is extracted from the Indonesia Stock Exchange's Annual reports from 2008 to 2019. We use the proxy debt to asset ratio for the independent variable as a proxy for agency problems (Popov \& Barbiero, 2018). An increase in the debt-toasset ratio reduces investment by a quarter of the standard deviation. The overhang mechanism explains that an increase in debt ratio to assets will reduce shareholders' rights in assets because it will be given to debtholders for the first time (Myers, 1977).

The independent variable as a proxy for our information asymmetry uses firm size and firm age. Smaller companies tend to have more prominent asymmetry (internal information) problems (Hwang et al., 2019). Furthermore, large-sized companies have more funding options than small-sized companies. Age, measured since going public, impacts funding sources' heterogeneity (Almazan \& Molina, 2005). The current authors use the proxy Ln (total assets) for size and Ln (Age) for age.

According to Moreira (2017), differences in the industry's characteristics would result in differences in leverage. For that reason, the authors use the analysis of variance (ANOVA). Furthermore, to determine the effect of leverage, firm age, and firm size, multiple regression analysis of panel data was used.

The data were collected from 2327 units of observation (Whole Industry-WI): 4.86\% from industry A (Agriculture), 13.45\% from the BIC (Basic Industry and Chemicals) 
industry, $8.89 \%$ from the CGI (Consumer Goods Industry) industry, $12.46 \%$ from the IUT industry (infrastructure, utilities, and transportation), 9.92\% from M (Mining) industry, 6.96\% from MI (Miscellaneous Industry) industry, 16.41\% from PRB (property, real estate, and building construction) industry, and $27.03 \%$ from TSI (trade, services, and investment). Our empirical approach explains how the independent variables are related to growth opportunities as the dependent variable. The correlation results show that the relationship between the independent variables is low, so regression analysis is carried out.

Table 1. Result of Correlation Analysis

\begin{tabular}{ccccc}
\hline & dar & age & size & $\begin{array}{c}\text { Sales- } \\
\text { growth }\end{array}$ \\
\hline dar & 1 & & & \\
age & 0.033379 & 1 & & \\
size & 0.111995 & 0.045458 & 1 & \\
$\begin{array}{c}\text { Sales- } \\
\text { growth }\end{array}$ & 0.007558 & -0.06881 & 0.009209 & 1 \\
\hline
\end{tabular}

\section{Results}

\section{The difference in Inter-Industry Leverage}

The skewness data shows that industry A, TSI, and WI have a leverage level below the median. Aside from all three industries mentioned above, all the remaining industries have a leverage level above the median. Thus, there is a difference in the leverage level of industry A, TSI, and WI with the remaining sectors. This result indicates that differences in risk and firm characteristics could result in differences in leverage

Table 2. Descriptive statistics on inter industry leverage

\begin{tabular}{|c|c|c|c|c|c|c|c|c|}
\hline Industry & $\mathrm{N}$ & Mean & $\begin{array}{l}\text { Std } \\
\text { Dev }\end{array}$ & $\begin{array}{l}\text { 25th quan- } \\
\text { tile }\end{array}$ & $\begin{array}{l}\text { Me- } \\
\text { dian }\end{array}$ & $\begin{array}{l}\text { 75th } \\
\text { quan- } \\
\text { tile }\end{array}$ & $\begin{array}{c}\text { Kurto- } \\
\text { sis }\end{array}$ & $\begin{array}{c}\text { Skew- } \\
\text { ness }\end{array}$ \\
\hline Agriculture & 113 & 0.452 & 0.226 & 0.257 & 0.468 & 0.607 & 5.464 & 1.147 \\
\hline $\begin{array}{c}\text { Basic Industry and } \\
\text { Chemicals }\end{array}$ & 313 & 0.479 & 0.195 & 0.334 & 0.471 & 0.616 & -0.757 & 0.111 \\
\hline Consumer Goods & & & & & & & & \\
\hline Industry & 207 & 0.404 & 0.170 & 0.262 & 0.388 & 0.541 & -0.890 & 0.231 \\
\hline $\begin{array}{l}\text { Infrastructure, Util- } \\
\text { ities and Transpor- } \\
\text { tation }\end{array}$ & 290 & 0.520 & 0.176 & 0.399 & 0.533 & 0.650 & -0.447 & -0.290 \\
\hline Mining & 231 & 0.478 & 0.195 & 0.318 & 0.463 & 0.616 & -0.669 & 0.224 \\
\hline $\begin{array}{c}\text { Miscellaneous In- } \\
\text { dustry }\end{array}$ & 162 & 0.508 & 0.189 & 0.367 & 0.491 & 0.660 & -0.959 & 0.051 \\
\hline $\begin{array}{l}\text { Property, Real Es- } \\
\text { tate and Building }\end{array}$ & & & & & & & & \\
\hline Construction & 382 & 0.462 & 0.175 & 0.336 & 0.474 & 0.581 & -0.610 & 0.118 \\
\hline Trade, Services and & & & & & & & & \\
\hline Investment & 629 & 0.480 & 0.219 & 0.321 & 0.468 & 0.633 & 13.305 & 1.530 \\
\hline Whole Industry & 2327 & 0.476 & 0.198 & 0.327 & 0.474 & 0.618 & 5.549 & 0.693 \\
\hline
\end{tabular}

The research finds different leverage variations between industries, at $16.9 \%$ due to different industries. Leverage firms have a greater variation than unleveraged firms due to the free cash flow hypothesis (Jensen \& Meckling, 1976). The free cash flow argument explains that a different growth rate characterizes each industry, so that leverage also varies (Das \& Roy, 2007). 
Table 3. ANOVA test on leverage inter industry

\begin{tabular}{cccccccc}
\hline Sources & SS & df & MS & F & P value & F crit & RMSSE \\
\hline Between Groups & 1.952 & 8 & 0.244 & 6.305 & 0.000 & 1.940 & 0.169 \\
Within Groups & 179.710 & 4645 & 0.039 & & & & \\
\hline Total & 181.661 & 4653 & 0.039 & & & &
\end{tabular}

We present time-series data for 2009 - 2019. The mean leverage in inter-industry is relatively stable, indicating that managers acting in shareholders' interests prevent conflicts with debtholders and encourage avoidance of debt overhang.

Figure 1. Time series on Inter-Industry Debt Ratio
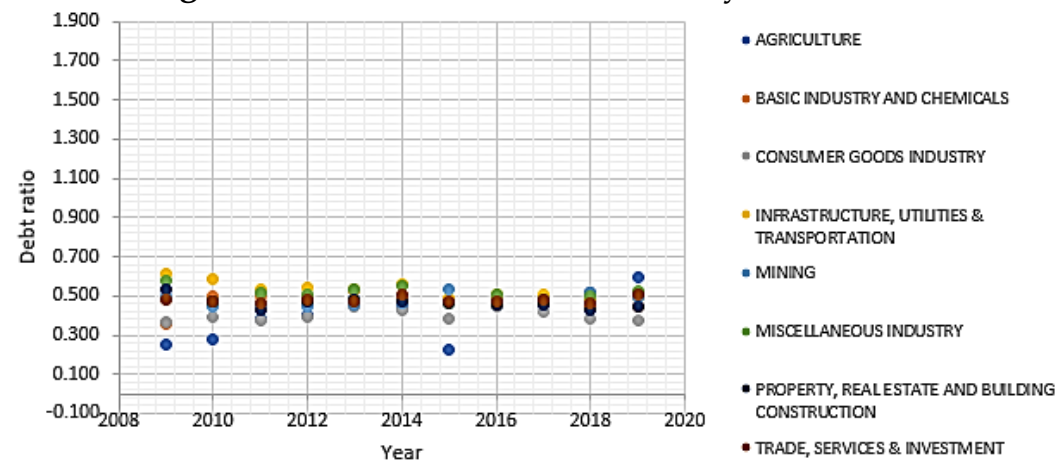

In 2009, the mean leverage was the most varied, while low variation was evident in 2013, indicating the need for leverage in response to growth differences. Companies in inter-industry tend to take time-series to try to prevent agency conflicts (Almazan \& Molina, 2005).

Table 4. Time series data on firm age

\begin{tabular}{|c|c|c|c|c|c|c|c|c|c|c|c|}
\hline & 2009 & 2010 & 2011 & 2012 & 2013 & 2014 & 2015 & 2016 & 2017 & 2018 & 2019 \\
\hline Age & 0.252 & 0.281 & 0.387 & 0.404 & 0.476 & 0.432 & 0.227 & 0.481 & 0.475 & 0.513 & 0.591 \\
\hline Agriculture & 0.361 & 0.495 & 0.497 & 0.473 & 0.527 & 0.493 & 0.485 & 0.487 & 0.490 & 0.449 & 0.447 \\
\hline Basic Industry and Chemicals & 0.363 & 0.393 & 0.375 & 0.389 & 0.448 & 0.432 & 0.387 & 0.448 & 0.417 & 0.383 & 0.378 \\
\hline Consumer Goods Industry & 0.616 & 0.583 & 0.534 & 0.544 & 0.529 & 0.559 & 0.493 & 0.505 & 0.503 & 0.483 & 0.492 \\
\hline \multicolumn{12}{|l|}{ Infrastructure, Utilities and } \\
\hline Transportation & 0.502 & 0.446 & 0.455 & 0.444 & 0.453 & 0.463 & 0.534 & 0.475 & 0.482 & 0.512 & 0.488 \\
\hline Mining & 0.574 & 0.468 & 0.518 & 0.511 & 0.530 & 0.554 & 0.459 & 0.508 & 0.474 & 0.498 & 0.524 \\
\hline Miscellaneous Industry & 0.531 & 0.474 & 0.431 & 0.470 & 0.479 & 0.467 & 0.460 & 0.452 & 0.455 & 0.428 & 0.446 \\
\hline \multicolumn{12}{|l|}{ Property, Real Estate and } \\
\hline Building Construction & 0.477 & 0.475 & 0.466 & 0.477 & 0.472 & 0.503 & 0.473 & 0.469 & 0.478 & 0.467 & 0.505 \\
\hline \multicolumn{12}{|l|}{ Trade, Services and } \\
\hline Investment & 0.460 & 0.452 & 0.458 & 0.464 & 0.489 & 0.488 & 0.440 & 0.478 & 0.472 & 0.467 & 0.484 \\
\hline Minimal & 0.252 & 0.281 & 0.375 & 0.389 & 0.448 & 0.432 & 0.227 & 0.448 & 0.417 & 0.383 & 0.378 \\
\hline Maximal & 0.616 & 0.583 & 0.534 & 0.544 & 0.530 & 0.559 & 0.534 & 0.508 & 0.503 & 0.513 & 0.591 \\
\hline
\end{tabular}

The Difference between Age and Size in Inter-Industry

Companies in the inter-industry have a mean age below the median age, and with a negative kurtosis, it is relatively heterogeneous. The mean age variation was more significant in the CGI and MI industries than in other industries.

Table 5. Data description on firm age intra industry

\begin{tabular}{ccccccc} 
& \multicolumn{3}{c}{ Std } & 25th & 75th \\
Industry & $\mathrm{N}$ & Mean & Dev & quantile & Median & quantile \\
\hline
\end{tabular}




\begin{tabular}{|c|c|c|c|c|c|c|c|c|}
\hline \multicolumn{9}{|l|}{ Age } \\
\hline Agriculture & 113 & 2.470 & 0.596 & 2.197 & 2.485 & 3.091 & 0.866 & -0.682 \\
\hline \multicolumn{9}{|l|}{ Basic Industry and } \\
\hline Chemicals & 313 & 2.761 & 0.699 & 2.303 & 3.135 & 3.219 & 1.414 & -1.468 \\
\hline \multicolumn{9}{|l|}{ Consumer Goods } \\
\hline Industry & 207 & 2.747 & 0.720 & 2.197 & 3.178 & 3.258 & 0.708 & -1.328 \\
\hline \multicolumn{9}{|l|}{ Infrastructure, Utilities } \\
\hline and Transportation & 290 & 2.293 & 0.633 & 1.946 & 2.197 & 2.773 & 0.253 & -0.641 \\
\hline Mining & 231 & 2.581 & 0.472 & 2.303 & 2.485 & 2.944 & 2.355 & -0.960 \\
\hline Miscellaneous Industry & 162 & 2.803 & 0.719 & 2.485 & 3.135 & 3.296 & 2.173 & -1.612 \\
\hline \multicolumn{9}{|l|}{$\begin{array}{c}\text { Property, Real Estate } \\
\text { and Building }\end{array}$} \\
\hline Construction & 382 & 2.620 & 0.622 & 2.303 & 2.602 & 3.178 & 1.080 & -1.041 \\
\hline \multicolumn{9}{|l|}{ Trade, Services and } \\
\hline Investment & 629 & 2.583 & 0.627 & 2.079 & 2.773 & 3.091 & 0.727 & -0.995 \\
\hline Whole Industry & 2327 & 2.601 & 0.653 & 2.197 & 2.708 & 3.178 & 0.697 & -1.006 \\
\hline
\end{tabular}

The mean age difference was due to $2.3 \%$ differences in the industry, which was below the median (positive skewness), and that inter-industry had mean age heterogeneity (negative kurtosis).

Table 6. ANOVA test on firm age intra industry

\begin{tabular}{ccccccccc}
\hline & & & & & & & & Omega \\
Sources & SS & df & MS & F & P value & F crit & RMSSE & Sq \\
\hline Between Groups & 48.950 & 8 & 6.119 & 14.682 & 0.000 & 1.940 & 0.245 & 0.023 \\
Within Groups & 1935.800 & 4645 & 0.417 & & & & & \\
\hline Total & 1984.750 & 4653 & 0.427 & & & & &
\end{tabular}

Negative skewness is shown when most companies in industries A, CGI, M, and PRB have total assets above the median while others are below the median. Industry A and MI have a positive kurtosis, so the total assets' variation is lower than that owned by other sectors.

Table 7. Descriptive statistic on firm size

\begin{tabular}{|c|c|c|c|c|c|c|c|c|}
\hline Industry & $\mathrm{N}$ & Mean & $\begin{array}{l}\text { Std } \\
\text { Dev }\end{array}$ & $\begin{array}{c}\text { 25th } \\
\text { quantile }\end{array}$ & Median & $\begin{array}{c}\text { 75th } \\
\text { quantile }\end{array}$ & Kurtosis & Skewness \\
\hline \multicolumn{9}{|l|}{ Size } \\
\hline Agriculture & 113 & 29.262 & 1.162 & 28.609 & 29.335 & 30.084 & -0.625 & 0.364 \\
\hline \multicolumn{9}{|l|}{ Basic Industry and } \\
\hline Chemicals & 313 & 28.365 & 1.329 & 27.460 & 28.369 & 29.168 & 0.339 & -0.140 \\
\hline \multicolumn{9}{|l|}{ Consumer Goods } \\
\hline Industry & 207 & 28.083 & 1.284 & 27.206 & 27.926 & 28.845 & 0.444 & -0.014 \\
\hline \multicolumn{9}{|l|}{$\begin{array}{l}\text { Infrastructure, } \\
\text { Utilities and }\end{array}$} \\
\hline Transportation & 290 & 28.856 & 1.531 & 27.886 & 28.752 & 29.809 & -0.004 & -0.692 \\
\hline Mining & 231 & 29.118 & 1.468 & 28.242 & 29.205 & 30.259 & -0.517 & -0.359 \\
\hline \multicolumn{9}{|l|}{ Miscellaneous } \\
\hline Industry & 162 & 28.090 & 1.229 & 27.186 & 27.730 & 28.631 & 0.960 & 0.025 \\
\hline \multicolumn{9}{|c|}{$\begin{array}{l}\text { Property, Real Estate } \\
\text { and Building }\end{array}$} \\
\hline Construction & 382 & 28.899 & 1.338 & 28.038 & 28.942 & 29.893 & -0.188 & -0.311 \\
\hline
\end{tabular}




\begin{tabular}{ccccccccc}
$\begin{array}{c}\text { Trade, Services and } \\
\text { Investment }\end{array}$ & 629 & 28.161 & 1.433 & 26.890 & 28.197 & 29.243 & 0.046 & -0.527 \\
\hline Whole Industry & 2327 & 28.533 & 1.439 & 27.434 & 28.515 & 29.563 & 0.045 & -0.572
\end{tabular}

The finding also found that the differences in leverage are 3.9\% caused by the firm's size due to differences in asset ownership between industries. The variation in total assets was greater in the CGI because it grew larger than others in the observation period.

Table 8 . ANOVA test on firm size intra industry

\begin{tabular}{ccccccccc}
\hline & & & \multicolumn{1}{c}{ P } & F & \multicolumn{2}{c}{ Omega } \\
Sources & SS & df & MS & F & value & crit & RMSSE & Sq \\
\hline Between Groups & 389.996 & 8 & 48.750 & 24.481 & 0.000 & 1.940 & 0.321 & 0.039 \\
Within Groups & 9249.644 & 4645 & 1.991 & & & & & \\
\hline Total & 9639.640 & 4653 & 2.072 & & & & &
\end{tabular}

The findings show that: (1) There is a low correlation between the independent variables, and (2) There are differences in leverage, age, and sizes between industries. The findings of the independence of the independent variables and inter-industry differences are predicted not to produce a growth opportunity bias, allowing regression testing to be carried out.

\section{Discussion: How is Growth Sales with the presence of a debt ratio, firm age, and firm size}

Firm value is generated from financed assets in exploiting growth opportunities through profitable investment (Myers, 1977). The managers of independent companies have discretion in making investment decisions based on shareholders' interests, causing them to reject investments with positive NPV (underinvestment). Debt overhang causes companies to lose growth, turning it into a risk for debtholders. The situation above encourages agency conflicts between shareholders and debtholders, impacting the companies' inability to pay debts. The increased risk of companies being unable to pay the debt causes debtholders to raise interest rates and limit lending, forcing shareholders to seek cheaper external sources of funding (i.e., capital market). In-place asset financing or interindustry DAR ranges from $22.7 \%$ to $61.6 \%$. Thus, the company keeps the debt from becoming overhang from time to time. Managers often decide to underinvest or conduct risk-shifting when a debt overhang occurs, causing a decrease in growing sales. However, when there is no debt overhang, leverage does not affect sales growth (model 2). As a result, there is no underinvestment or risk-shifting.

In East Asia, including Indonesia, ownership structure does not separate ownership and control, allowing managers to always act in shareholders' interests (Claessens et al., 2000). The ownership structure of companies in Indonesia tends to be concentrated, with $65.14 \%$ controlled by the majority shareholders and $66.45 \%$ controlled by individuals or groups, or families (Rusmin et al., 2011). They added that, in some cases, family members are also placed as independent commissioners to maintain family control over the company. To maintain control and prevent this conflict, family companies will place their members as debtholders (Villalonga et al., 2015).

Shareholders have an interest in maintaining the family company or controlling shareholders. Thus, in older companies, the ownership structure tends to be concentrated. Shareholders do not want to lose ownership to long-running companies, so they maintain the debt level not to cause debt overhang. This condition trigger shareholders to avoid risky debt so that the interest of the debtholders is maintained. As such, the relationship between debtholders and shareholders can be in line with one another. Companies in Indonesia are mostly family-owned and are more oriented towards ensuring long-term goals, safeguarding family reputation, and maintaining togetherness by not diversifying the ownership (Anderson et al., 2005). 
Table 9. Regression Analysis

Dependent Variable: Growth Sales

\begin{tabular}{ccc} 
& 1 & 2 \\
\hline Debt Asset Ratio & 0.009 & 0.010 \\
p-value & 0.716 & 0.680 \\
Age & & $-0.024^{*}$ \\
p-value & & 0.001 \\
Size & & 0.002 \\
p-value & 0.000 & 0.584 \\
\hline R Square & 0.000 & 0.005 \\
Adj R Square & 2327 & 2327
\end{tabular}

The existence of agency problems between shareholders and bondholders results in asymmetric information. Bondholders do not know the quality of investment information because of the opportunistic managerial and shareholders, limiting lending and increasing the interest rate. No agency problem is evident, but information asymmetry is an issue that negatively affects growth sales.

Model 2 shows that older firms have fewer information asymmetry problems. The age measured since going public impacts the funding sources' heterogeneity (Almazan \& Molina, 2005). As an implication, companies have other sources of funding other than debt. Agency problems do not coincide with asymmetric information, in contrast to the initial hypothesis that explains the relationship (Cariola et al., 2011; La Rocca et al., 2007).

Older companies have fewer asymmetric information because they provide better information compared to smaller companies. Thus, the public becomes more aware of older companies' information than younger companies (Tayem, 2018). As a result, when there is no debt overhang due to risky debt, older companies tend to lower growth opportunities. An older company without agency conflict and asymmetric information have higher retention of control. Shareholders can obtain external funds more quickly because there is no information asymmetry problem, but they still use debt and experience debt overhangs. Older companies concentrate more on ownership (Claessens et al., 2000) and still prioritizes debt as a source of funding. They are afraid of losing their company during a debt overhang, resulting in asset takeover by debtholders.

The impact is the use of growth opportunities through debt restriction, although it can increase debt because there is no information asymmetry. Without agency conflict, the information asymmetry caused by the firm size only increases by $1 \%$, so it has a significant probability of increasing the growth opportunity by $0.1 \%$

\section{Conclusion}

With the characteristics of being dominated by a concentrated ownership structure and family, companies in Indonesia provide evidence that there is no excessive debt, let alone a debt overhang. Shareholders maintain a relatively smaller debt ratio than the assets in place used to take advantage of growth opportunities. This situation prevents conflicts between shareholders and debtholders due to underinvestment and risk-shifting. Interestingly, when there is no agency conflict (cheap cost of debt) and older companies have low assimilation problems (access to equity issuance is better), the company should increase debt or issue equity. Shareholders still maintain low debt and do not increase equity because of low information asymmetry to avoid dilution.

Overall, companies in Indonesia with a unique structure do not have a debt overhang problem. Older companies with low information asymmetry keep their debt relatively stable and use them in a limited way to take advantage of growth opportunities.

The limitation of this research is that the study could not explore the variable of family ownership structure due to Indonesia's pyramid ownership structure. Future studies 
are suggested to use monthly pyramid ownership structure data to show the consistency of leverage, firm age, and firm size as a future research agenda. More factors should also be included in the regression model to capture more determinants of growth opportunities in the perspective of agency theory and asymmetric information, thereby reducing the gap between expected and realized results. Finally, the paper performed several statistical tests to test the relevance of regression and found it consistent, showing that research data is reliable

Author Contributions: S.M. is generating an idea for this research, he proposes and contributing for the introduction and research method A.Y. arranges and develop literature review, data analysis, and conclusion. A.P.W. analyzes data and contributes to the discussion. All authors have read and agreed to the published version of the manuscript

Funding: This research was funded by the Indonesian Ministry of Education, Culture and Research Technology through Research Grant Universitas Negeri Semarang in 2020

Acknowledgments: Thank You to Suwito E.P, Vice Lembaga Penelitian dan Pengabdian kepada Masyarakat Universitas Negeri Semarang for opportunities the research

Conflicts of Interest: There is no conflict of interest regarding this research.

\section{References}

1. Almazan, A., \& Molina, C. A. (2005). Intra-industry capital structure dispersion. Journal of Economics and Management Strategy, 14(2), 263-297. https://doi.org/10.1111/j.1530-9134.2005.00042.x

2. Anderson, R. C., Mansi, S. A., \& Reeb, D. M. (2005). Founding Family Ownership and the Agency Cost of Debt. SSRN Electronic Journal, 202. https://doi.org/10.2139/ssrn.303864

3. Ari, D. (2017). The Impact of Fundings Sources, Ownership Structure, Diversification External Factors on Dividend, Investment, and Firm Value. Russian Journal of Agriculture and Socioeconomic Sciences, 3(March), 53-71.

4. Billett, M. T., King, T. H. D., \& Mauer, D. C. (2007). Growth Opportunities and The Choice of Leverage, Debt Maturity, and Covenants. Journal of Finance, 62(2), 697-730. https://doi.org/10.1111/j.1540-6261.2007.01221.x

5. Brito, J. A., \& John, K. (2002). Leverage and Growth Opportunities: Risk-Avoidance Induced by Risky Debt. SSRN Electronic Journal, 212. https://doi.org/10.2139/ssrn.269580

6. Cariola, A., La Rocca, M., \& La Rocca, T. (2011). Overinvestment and Underinvestment Problems: Determining Factors, Consequences and Solutions. SSRN Electronic Journal. https://doi.org/10.2139/ssrn.835364

7. Claessens, S., Djankov, S., \& Lang, L. H. P. (2000). The separation of ownership and control in East Asian Corporations. In Journal of Financial Economics (Vol. 58, Issues 1-2). https://doi.org/10.1016/s0304-405x(00)00067-2

8. Das, S., \& Roy, M. (2007). Inter-Industry Differences in Capital Structure: The Evidence from India. Finance India, $21(2), 517$.

9. Degryse, H., \& Jong, A. De. (2001). Investment and Internal Finance: Asymmetric Information or Managerial Discretion? (REPORT SERIES RESEARCH IN MANAGEMENT).

10. Frank, M., \& Goyal, V. (2003). Testing the Pecking Order Theory of Capital Structure. In Journal of Financial Economics (Vol. 67, Issue 2). https://doi.org/10.1016/S0304-405X(02)00252-0

11. Graham, J. R., \& Leary, M. T. (2011). A Review of Empirical Capital Structure Research and Directions for the Future. Annu. Rev. Financ. Econ, 309-345. https://doi.org/10.2139/ssrn.1729388

12. Harijono, H., \& Tanewski, G. (2012). Does Legal Transplantation Work? The Case of Indonesian Corporate Governance Reforms. Journal of Indonesian Economy and Business, 27(1), 73-97. https://doi.org/10.2139/ssrn.1772808

13. Hwang, J. Y. T., Qi, G. Z., Hamdan, R. bt., Liwan, A., Hui, J. K. S., Razali, M. W. bin M., \& Abdullah, M. A. bin. (2019). The Effects of Ownership Structures on Firm Information Asymmetry in Malaysia. International Journal of Academic Research in Business and Social Sciences, 9(9), 950-977. https://doi.org/10.6007/ijarbss/v9-i9/6384

14. Jensen, M. ., \& Meckling, W. (1976). Theory of The Firm: Managerial Behavior, Agency Cost and Ownership Structure. Journal of Financial Economics 3, 3(1), 305-360. https://doi.org/10.1177/0018726718812602

15. La Porta, R., Lopez-de-Silanes, F., \& Shleifer, A. (1999). Corporate ownership around the world. Journal of Finance, 54(2), 471517. https://doi.org/10.1111/0022-1082.00115

16. La Rocca, M., La Rocca, T., \& Cariola, A. (2007). Overinvestment and Underinvestment Problems: Determining Factors, Consequences and Solutions. Corporate Ownership and Control, 5(1), 79-95. https://doi.org/10.22495/cocv5i1p7

17. Leclerc, B. (2016). "Debt overhang and return for investors : an inter - sector analysis "Debt overhang and return for investors : an inter - sector analysis [UNIVERSITE CATHOLIQUE DE LOUVAIN]. file://C:/Users/Asus/Downloads/Leclerc_60581100_2016.pdf

18. Mondosha, M., \& Majoni, A. (2018). The Impact of Leverage on Investment Decisions for South African Firms with Different Growth Opportunities. Journal of Economic and Financial Sciences, 11(1), 1-7. https://doi.org/10.4102/jef.v11i1.192

19. Moreira, P. (2017). Leverage variation and its relation to the industry characteristics . (Issue April). Universidade Católica Portuguesa.

20. Müller, E. (2011). Benefits of Control, Capital Structure and Company Growth. SSRN Electronic Journal, 05. https://doi.org/10.2139/ssrn.776364 
21. Myers, S. . (1977). Determinants of Corporate Borrowing*. Journal of Financial Economics, 5, 147-175. https://doi.org/10.1253/circj.CJ-16-0846

22. Nursechafia, \& Muthohharoh, M. (2014). Aan-Early Warninig Signal of Sovereign Debt Crisis in Indonesia. Jurnal Ekonomi Islam, 5(2), 175-188.

23. Popov, A., \& Barbiero, F. (2018). WORKING PAPER SERIES: Debt overhang and investment efficiency. Accounting $\mathcal{E}$ Finance, 24(1), 75-75. Website www.ecb.europa.eu\%0A

24. Rossieta, H. (2009). Risk Signal, Financial Derivatives Transactions and The Indonesian GAPP. 10.Th Annual Asiian Academic Accounting Association Conference Proceedings, 1490-1509. http://www.ghbook.ir/index.php?name= مجموعه مقالات دومين هم انديشى

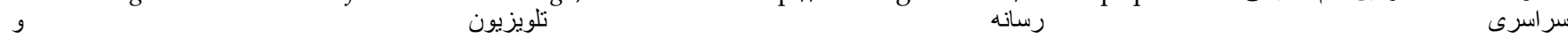
سكو لاريسم\&option=com_dbook\&task=readonline\&book_id=13629\&page=108\&chkhashk=03C706812F\&Itemid=218\&lang=fa\&tm $\mathrm{pl}=$ component

25. Rusmin, R., Tower, G., Achmad, T., \& Neilson, J. (2011). Concentrated family ownership structures weakening corporate governance: A developing country story. Corporate Ownership and Control, 8(2 A), 96-107. https://doi.org/10.22495/cocv8i2p9

26. Sadia, W., Arnyana, I. B. P., \& Muderawan, I. W. (2013). Model Pendidikan Karakter Terintegrasi Pembelajaran Sains. Jurnal Pendidikan Indonesia, 2(2), 209-220.

27. Stein, J. C. (2001). Agency, information and corporate investment (Working Paper 8342; NBER Working Paper Series, Vol. 1).

28. Tayem, G. (2018). The Determinants of Debt Maturity: The Case of Jordan. Academy of Accounting and Financial Studies Journal, 22(1), 1-13.

29. Taylor, P. (2013). What Do We Know About the Role of Financial Reporting in Debt Contracting and Debt Covenants? Accounting and Business Research, 43(4), 386-417. https://doi.org/10.1080/00014788.2013.798551

30. Villalonga, B., Amit, R., Trujillo, M. A., \& Guzmán, A. (2015). Governance of Family Firms. Annual Review of Financial Economics, 7(May 2016), 635-654. https://doi.org/10.1146/annurev-financial-110613-034357

31. Warjiyo, P. (2015). Indonesia: Changing Patterns of Financial Intermediation and Their Implications for Central Bank Policy. In BIS Paper (Issue 83). 